\title{
Review \\ Vitamin D in Inflammatory Bowel Diseases. Mechanisms of Action and Therapeutic Implications
}

\author{
Filippo Vernia (D), Marco Valvano (D), Salvatore Longo (D), Nicola Cesaro, Angelo Viscido (D) and Giovanni Latella \\ Gastroenterology Unit, Department of Life, Health and Environmental Sciences, University of L'Aquila, \\ Piazza S. Tommasi, Coppito, 67100 L'Aquila, Italy; filippo.vernia1@gmail.com (F.V.); \\ valvano.marco@libero.it (M.V.); salvator.longo@gmail.com (S.L.); dott.nicolacesaro@gmail.com (N.C.); \\ angelo.viscido@univaq.it (A.V.) \\ * Correspondence: giolatel@tin.it, Tel.: +39-0862-434735; Fax: +39-0862-433425
}

check for

updates

Citation: Vernia, F.; Valvano, M.;

Longo, S.; Cesaro, N.; Viscido, A.;

Latella, G. Vitamin D in

Inflammatory Bowel Diseases.

Mechanisms of Action and

Therapeutic Implications. Nutrients

2022, 14, 269. https://doi.org/

$10.3390 /$ nu14020269

Academic Editors:

Konstantinos Papadimitriou and

Sousana Papadopoulou

Received: 26 November 2021

Accepted: 4 January 2022

Published: 9 January 2022

Publisher's Note: MDPI stays neutral with regard to jurisdictional claims in published maps and institutional affiliations.

Copyright: (C) 2022 by the authors. Licensee MDPI, Basel, Switzerland. This article is an open access article distributed under the terms and conditions of the Creative Commons Attribution (CC BY) license (https:// creativecommons.org/licenses/by/ $4.0 /)$.
Abstract: (1) Background: Vitamin D is an immunoregulatory factor influencing intestinal homeostasis. Recent evidence supports a central role of this micronutrient in the course of Inflammatory Bowel Diseases (IBD). This narrative review aims to provide a general overview of the possible biological mechanisms of action of vitamin D and its therapeutic implications in IBD. (2) Methods: A systematic electronic search of the English literature up to October 2021 was performed using Medline and the Cochrane Library. Only papers written in English that analyzed the role of vitamin D in IBD were included. (3) Results: In vitro and animal studies reported that vitamin D signaling improves epithelial barrier integrity regulating the expression of several junctional proteins, defensins, and mucins, modulates the inflammatory response, and affects gut microbiome composition. Recent studies also suggest that vitamin D deficiency is highly prevalent among IBD patients and that low serum levels correlate with disease activity and, less clearly, with disease course. (4) Conclusions: An increasing body of evidence suggests some role of vitamin $\mathrm{D}$ in the pathophysiology of IBD, nonetheless the underlying mechanisms have been so far only partially elucidated. A strong correlation with disease activity has been reported but its implication in the treatment is still undefined. Thus, studies focused on this issue, the definition of vitamin D levels responsible for clinical effects, and the potential role of vitamin $\mathrm{D}$ as a therapeutic agent are strongly encouraged.

Keywords: micronutrient; inflammation; IBD; Crohn's disease; ulcerative colitis

\section{Introduction}

Vitamin D regulates calcium and phosphate metabolism, contributing to optimal bone homeostasis [1]. Besides effects on bone, vitamin D has also been linked to a wide range of biological activities, including modulation of gut mucosal immunity and the integrity of the intestinal barrier [2,3]. Consequently, vitamin D deficiency has been associated with the activity of immune-mediated diseases, including inflammatory bowel disease (IBD). A pathogenetic role in chronic inflammatory diseases, including IBD, has also been advocated.

Vitamin D, a fat-soluble steroidal hormone, is present in humans in two main forms: vitamin D2, (ergocalciferol, from vegetables) and vitamin D3 (cholecalciferol, from animal sources). Both are provided by dietary intake and supplementation.

Vitamin D3, the more biologically active compound, is synthesized in the skin in response to ultraviolet light [4]. Cholesterol is converted to 7-dehydrocholesterol in the plasma membrane of epidermal cells. The 7-dehydrocholesterol is then converted to pre-vitamin D which will be further converted into vitamin D [4]. The vitamin is then released into the circulation, bound to Vitamin D Binding Protein (VDBP) [4]. Following endogenous synthesis or intestinal absorption, vitamin $\mathrm{D}$ is carried to the liver where it is converted by vitamin D 25-hydroxylase into its major circulating form, 25hydroxyvitamin $\mathrm{D}[25(\mathrm{OH}) \mathrm{D}]$. The $25(\mathrm{OH}) \mathrm{D}$ is then further converted into its active 
form, 1,25-dihydroxyvitamin $\mathrm{D}\left[1,25(\mathrm{OH})_{2} \mathrm{D}\right]$, by the renal cytochrome $\mathrm{P} 450$ enzyme, 25hydroxyvitamin D-1 $\alpha$-hydroxylase (CYP27B1) [5] (Figure 1).

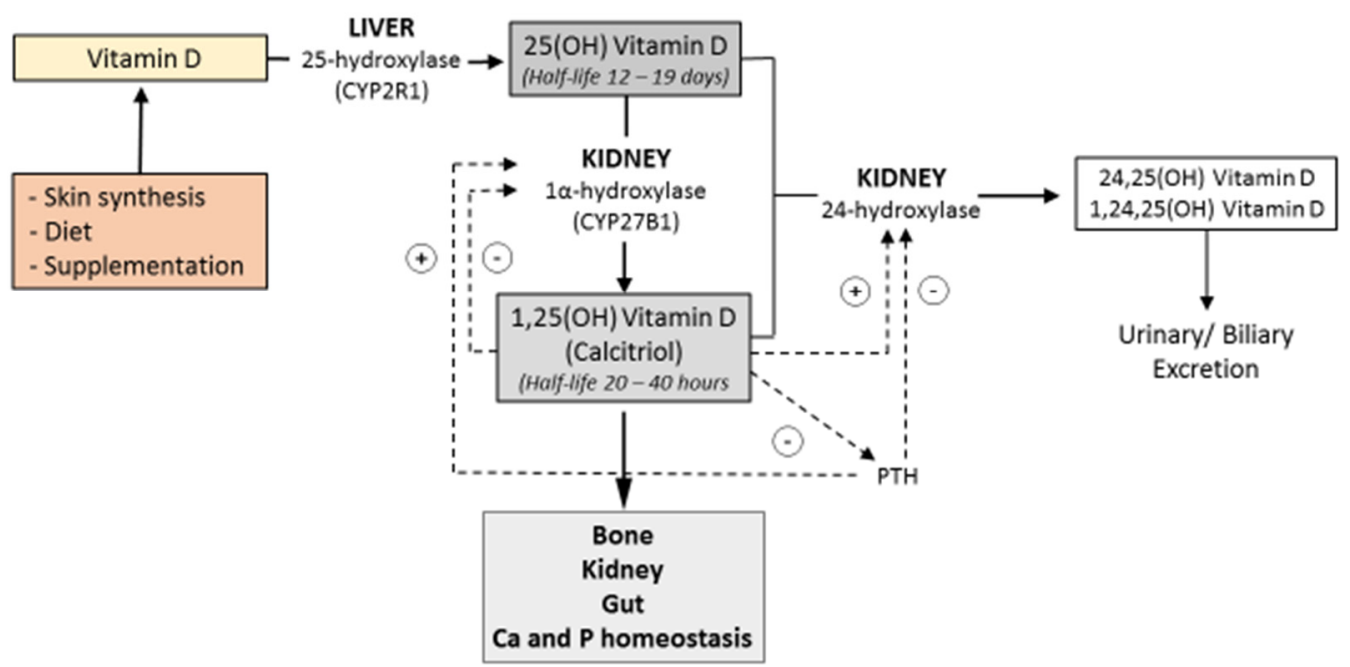

Figure 1. Vitamin D is synthesized in the skin in response to ultraviolet light or provided by the diet. It is first converted to 25-hydroxyvitamin D3 by hydroxylation occurring in the liver and then further converted into its active metabolite, 1,25-dihydroxyvitamin D3, in the kidney. Ca = calcium; P = phosphate; CYP2R1 = Cytochrome P450 Family 2 Subfamily R Member 1; CYP27B1= Cytochrome P450 Family 27 Subfamily B Member 1; 25(OH) vitamin D = 25-hydroxyvitamin D; 1,25 (OH) Vitamin $\mathrm{D}=1$,25-dihydroxyvitamin D.

Opposite effects are exerted in the kidney by 1,25-dihydroxyvitamin D3 and parathyroid hormone (PTH) on the enzymes $1 \alpha$-hydroxylase and 24- hydroxylase, regulating the production and excretion of the active form of the vitamin.

Bone, kidney, and gut function, and regulation of calcium and phosphate homeostasis, result from the action of 1,25-dihydroxyvitamin D3.

Both 25(OH)D and 1,25(OH $)_{2}$ D are degraded through a third hydroxylation at carbon 24 or carbon 23 and converted by oxidation to calcitroic acid [6], which is excreted by the kidney or enters the enterohepatic circulation through bile [6].

\section{Methods}

A systematic electronic search of the English literature up to October 2021 was performed using Medline, and the Cochrane Library. The search strategy used a combination of Medical Subject Headings (MeSH) and keywords as follows: "vitamin D", "vitamin D deficiency", "vitamin D receptor", “VDR", "IBD”, "Inflammatory Bowel Disease", “Crohn", "ulcerative colitis", "inflammation", "cytokines", "immune system", "gut microbiota", "intestinal barrier", "epithelial barrier", "epithelial permeability", "epithelium", "intestinal homeostasis", "inflammatory response", "short-chain fatty acids", "SCFA", "butyrate", "response to therapy", "therapy", "biologics".

Four authors selected relevant studies by screening the abstracts. Additional references were included after a review of the bibliography of the identified papers and review articles. Any difference was resolved by consensus, referring to the original articles.

Out of 2687 citations, 119 relevant articles were selected and included in the present narrative review.

\section{Vitamin D Deficiency}

Vitamin D shortage is a common health issue, but a shared definition of vitamin $\mathrm{D}$ deficiency is not available. Most guidelines suggest that levels below 20-30 ng/mL (50-75 $\mathrm{nmol} / \mathrm{L})$ are considered insufficient $[7,8]$. These figures are primarily based on the 
skeletal effects of vitamin D, while the minimum level required for extra-skeletal effects is less clearly defined.

According to the World Health Organization (WHO) guidelines, vitamin D shortage is further subdivided into deficiency and insufficiency, defined as serum $25(\mathrm{OH}) \mathrm{D}$ levels below 10 and $20 \mathrm{ng} / \mathrm{mL}$, respectively [9]. However, higher cut-offs are proposed by the Endocrinological Society [8].

The prevalence of vitamin D deficiency (serum $25-\mathrm{OH}-\mathrm{D}<40 \mathrm{nmol} / \mathrm{L}$ ) in the general population is high, ranging between $30 \%$ [10] and $47 \%$ [11], in relation to the geographic area considered [12]. The prevalence is higher in patients at risk of vitamin D deficiency due to different causes, malabsorptive disorders, IBD included.

In a recent Italian study [13] mean vitamin D concentration in IBD patients was $18.9 \pm 10.2 \mathrm{ng} / \mathrm{mL}$. Insufficiency was present in $62 \%$ of IBD patients, and deficiency was observed in $22 \%$. The Odds Ratio of vitamin D deficiency versus controls was 3.2, higher than that was reported in a recent meta-analysis in the IBD series (OR 1.64) [14]. The strict exclusion of subjects taking vitamin supplementation in the Italian cohort explains the difference [13].

IBD patients are known to be at particularly high risk for vitamin D deficiency [13] for several reasons including intestinal inflammation leading to impaired absorption of nutrients, bile acid malabsorption, restricted dietary intake, reduced sunlight exposure [15], or as a consequence of immunosuppressive treatment with thiopurines [16].

The prevalence of osteopenia is also high in IBD ranging from 32 to $36 \%$, while the prevalence of osteoporosis is present in $7-15 \%$ of patients $[17,18]$. The mean bone mineral density (BMD) and Z-scores for IBD patients versus controls were also decreased [19]. The relative risk (RR) for bone fractures is increased in IBD patients when compared to the general population, as confirmed by two recent metanalyses $[19,20]$. This proves true both for the global fracture risk (RR 1.38, 95\% CI 1.11-1.73) and for vertebral fractures (odds ratio 2.26 , 95\% CI 1.04-4.90) [19].

Low circulating levels of vitamin $\mathrm{D}$ is an important risk factor for osteopenia and osteoporosis in patients with IBD [21,22].

Nonetheless, the issue of vitamin $\mathrm{D}$ shortage in IBD is addressed by the British guidelines, but not by the more recent European Crohn's and Colitis Organisation (ECCO) [23,24] and American College of Gastroenterology (ACG) guidelines [25,26]. Surprisingly enough the need for vitamin D supplementation was pointed out by 2017 [27], but not by 2020 [23,24] ECCO guidelines.

Besides vitamin D deficiency, reduced levels of vitamin K or magnesium, as well as increased levels of PTH secondary to low vitamin D levels, may also contribute to bone loss. Additional important risk factors for osteopenia/osteoporosis include chronic ongoing inflammation and corticosteroid therapy. It is well known that bone loss is tightly linked to immune system activation occurring during flares in chronic inflammation, mainly via TNF- $\alpha$, IL-1 $\beta$ IL6, IL15, IL17, IFN $\gamma$, and receptor activator of nuclear factor kappa-B ligand (RANKL). Steroids may also contribute to bone loss by increasing RANKL and reducing osteoprotegerin levels. Disability or reduced physical activity caused by the active disease may be involved in the alteration of bone metabolism.

\section{Vitamin $D$ and Inflammation}

The biological activity of $1,25(\mathrm{OH})_{2} \mathrm{D}$ is mediated by the vitamin $\mathrm{D}$ receptor (VDR), a member of the nuclear hormone receptor superfamily, expressed in differing organs, small and large bowel included [28]. A growing body of evidence suggests that vitamin D /VDR signaling affects the expression of several genes, regulates the immune system, and modulates the inflammatory response in experimental models of IBD [29], and humans [30,31]. Some evidence supports its role on the integrity of the mucus layer and underlying epithelium, and the composition of the microbiota (Figure 2). These issues will be addressed in the following paragraphs. 


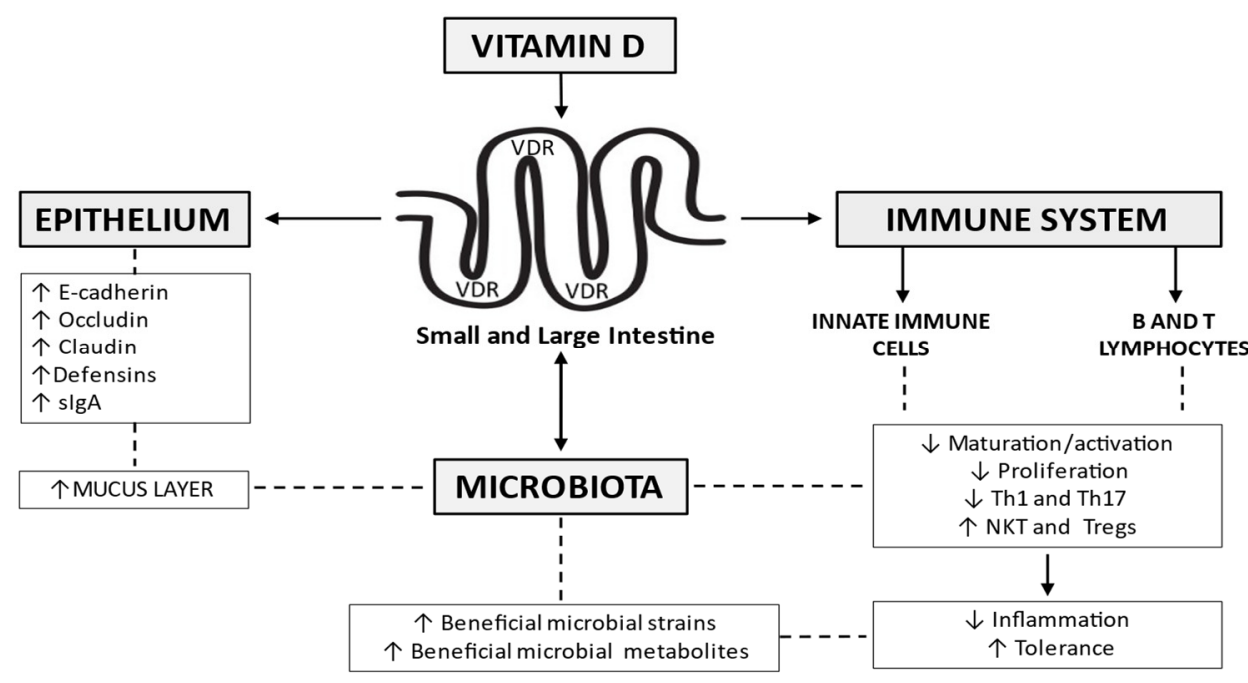

Figure 2. Vitamin D signaling affects the expression of several genes, regulates the immune system, and modulates the inflammatory response. It helps maintain epithelial integrity, through the regulation of tight junctions and adherens junctions' components, as well as the release of antimicrobial peptides like the defensins. A role in the integrity of the mucus layer, as well as the composition of the gut microbiome, has been advocated. Th = T helper cells; NKT = natural killer $\mathrm{T}$ cells; Tregs = regulatory $\mathrm{T}$ cells; sIgA = secretory immunoglobulin $\mathrm{A} ; \mathrm{VDR}=$ vitamin $\mathrm{D}$ receptor.

\subsection{Intestinal Epithelial Cells and Vitamin D}

VDR is highly expressed in normal gut epithelial cells [32,33]. A surface-to-crypt gradient is present, with the highest expression of VDR in the crypts [32,33]. The vitamin/VDR signaling pathway plays a primary role in the control of epithelial permeability, regulating the expression of several components of tight junctions (TJ) and adherens junctions (AJ), as well as the release of antimicrobial peptides and mucins [34] (Figure 2). In epithelial cells models, 1,25 (OH)2D3 increases the expression of E-cadherin and some TJ components, occludin, and claudins included [35]. The epithelial integrity is maintained by vitamin D/VDR signaling, also, through other mechanisms and provides a protecting effect against TNBS-induced colitis in mice [36], through inhibition of myosin light chain kinase (MLCK)-induced disruption of tight junctions. A direct role of vitamin D levels on mucus production has not been documented, and animal studies indicate that goblet cells lack VDR [37]. However, thinning of the mucus layer is present in CYP27B1 - / - mice [29]. This suggests that vitamin $\mathrm{D}$ indirectly modulates mucus secretion, possibly favoring adequate $\mathrm{Ca} 2+$ assimilation [38]. The additive effects of $\mathrm{Ca} 2+$ and vitamin D on MUC12 expression are also involved [39]. Another hypothesis links the effects of vitamin D/VDR on microbiota and mucus production. Modulation of microbiota affects SCFA/butyrate production, and the effects of butyrate on mucus controlling genes expression are well documented [40]. Animals kept on a vitamin D-depleted diet and mouse models specifically lacking vitamin $\mathrm{D}$ receptor (VDR) expression in the intestinal epithelium are more susceptible to experimental colitis [32,41,42], with different mechanisms of action of the vitamin. Diet-induced vitamin D deficiency increases intestinal permeability in mice models [43], and increased disease severity was reported in a dextran sulfate sodium (DSS) animal model after the deletion of epithelial cell VDR [44]. Interestingly, VDR/IL-10 double knockout (KO) mice develop colitis after 8 weeks as compared with single IL-10- or VDR-knockout animals that remain relatively healthy at that time [45]. Conversely, the induction of epithelial VDR reduces disease activity [32]. Data however are not fully concordant, considering that gut permeability is normal in VDR deficient (VDR - / - ) mice, which exhibit normal mucosal morphology both in the small [46] and in the large bowel [47]. Interestingly, in a mice model investigating the intestinal response to $1,25(\mathrm{OH})_{2} \mathrm{D}$, the transcriptional response of VDR was reported 6 hours after a single bolus of $1,25(\mathrm{OH})_{2} \mathrm{D}$. The effect was however limited to mature enterocytes [48]. All these data of experimental colitis in animal studies 
strongly support the pivotal role of vitamin D/VDR in maintaining an efficient mucosal barrier. The results on humans are less clear. Studies assessing VDR expression in IBD versus non-IBD control reported conflicting data as two studies [32,49] reported significantly lower VDR levels in inflamed IBD biopsies, while two other studies [50,51] were not able to detect overall significant differences, although VDR expression was inversely correlated with inflammatory activity. One study reported that VDR gene expression and protein immunohistochemical staining intensity were similar in different intestinal segments and between IBD patients and controls. However, a significantly lower VDR staining intensity was documented in inflamed samples versus non-inflamed epithelia, in IBD. [50]. The role of vitamin D in IBD patients, under stress conditions, was confirmed by other studies on colonic mucosa [41,52]. Mucosal inflammation was associated with a TNF- $\alpha$-mediated downregulation of VDR and an up-regulation of CYP27B1 [41,52]. The paradoxical effect of vitamin D/VDR on claudin-2, as vitamin D-dependent up-regulation of claudin-2, is considered central for the paracellular absorption of $\mathrm{Ca} 2+$ [53]. On the other hand, vitamin D/VDR signaling, reducing claudin-2 expression, and therefore epithelial paracellular permeability, seems to be protective in IBD [49,54]. Vitamin D/VDR signaling, by inhibiting the activation of $\mathrm{NF} K \mathrm{~B}$, can prevent p53 upregulated modulator of apoptosis (PUMA) induction, whose levels correlate with disease severity [55]. Moreover, in a model of DSS-induced colitis, VDR deficiency delayed mucosal healing [56]. The opposite was true for vitamin D supplementation $[57,58]$.

\subsection{Immune System and Vitamin D}

Macrophages, dendritic cells, B cells, and T cells all express VDR and are thus vitamin D targets $[59,60]$ (Figure 2). Furthermore, some immune cells directly produce small amounts of vitamin D. Similarly, to other extra-renal tissues, the production of 1,25D by the immune cells is modulated by the expression of Cyp27B1 [61]. Indeed, Cyp27B1 is induced via toll-like receptors or cytokines in macrophages and through $\mathrm{T}$ cell receptor stimulation in T cells [61-64]. Vitamin D inhibits the expression of IL-12 and toll-like receptors in dendritic cells and macrophages, as well as the dendritic cells-induced activation of T cells $[65,66]$. Conversely, the production of IL-10 by dendritic cells and cathelicidin in macrophages is enhanced by $1,25 \mathrm{D}[67,68]$. Less innate lymphoid type 3 cells (ILC3) and lower levels of IL-22 were reported in vitamin D deficient mice compared to mice with adequate levels of vitamin D [59]. In the acquired immune system, 1,25D inhibits the proliferation of B- and T-cells [69] and inhibits the production of IL-2, interferon (IFN)- $\gamma$, IL-17, and TNF- $\alpha$ from T-cells [69]. The stimulation of T cells by macrophages and dendritic cells is reduced in the presence of $1,25 \mathrm{D}$ [66]. Conversely, 1,25D induces the production of IL-10 and other anti-inflammatory cytokines by regulatory T-cells [70] and IL-4 by Th2 cells [69] (Figure 2). Vitamin D represents an attractive target for enhancing or restoring the protective function of NKT cells [71]. Vitamin D/VDR signaling indeed contributes to the development and function of NKT cells. A lower number of NKT cells compared with wild-type (WT) mice, was observed in both VDR-deficient and 1,25D3-deficient mice (Cyp27B1-/-) [72]. Defective iNKT cell maturation in the absence of the VDR was also suggested in the same study, as KO mice fail to express NK1.1, although they express normal levels of CD122. Vitamin D treatment also leads to increased production of IL-4 and IFN- $\gamma$ mice models [72]. The vitamin D-induced inhibition of T cells, reducing IFN- $\gamma$ and IL-17 levels, and the induction of regulatory cells (T regs, CD8 $\alpha \alpha$, and T) also supports the role of vitamin D/VDR in animal models of colitis [73]. This is in keeping with the results of experimental studies documenting that CD4 T cells from VDR KO and Cyp27B1 KO mice overproduce IFN- $\gamma$ and IL-17 cells compared to wild-type CD4 cells [74]. 1,25(OH) 2 D3 suppresses the proliferation of T cells in vitro [75,76]. VDR favors FoxP3+ T reg cells, which prevent the development of experimental colitis through the production of inhibitory cytokines such as IL-10 and TGF- $\beta$ [77] and FoxP3+ T reg cells are induced by $1,25(\mathrm{OH})_{2} \mathrm{D} 3$ treatments in vitro and in vivo [78]. Conversely, it has been reported that VDR KO mice have normal levels of FoxP3+ T reg cells compared to WT [79], further documenting the 
complexity of this issue. Other populations of regulatory T cells, such as CD $8 \alpha \alpha$, are also influenced by vitamin D, thus VDR KO mice have a reduced number of CD8 $\alpha \alpha$ T cells in the gut, due to block in maturation and proliferation of their precursors [80]. In the clinical setting chronic activation of Th1 and Th17 cells takes place [73], possibly as IBD patients are more frequently vitamin $\mathrm{D}$ deficient than control subjects [14].

\subsection{Gut Microbiota and Vitamin D}

Vitamin D influences the composition of the microbiome in healthy subjects [81] and the interaction is bidirectional. Genome-wide association studies (GWAS) indicate that human VDR gene variations correlate with changes in the intestinal microbiota [82], while the absence of intestinal VDR leads to dysbiosis in mice [44]. The bacterial microbiome does not express VDR, thus VDR signaling in epithelial and immune cells mediates the effects of vitamin D on intestinal flora [83] (Figure 2). As shortage or presence of vitamin D and VDR signaling modulate several substances influencing the bacterial-host interaction, as well as innate and acquired immune response, further changes in microbiome ensue. This view is supported by a large body of evidence, but this complex mosaic of interactions needs to be better clarified. VDR knock-out mice show defective Paneth cells function $[44,84]$, resulting in defective autophagy, granule exocytosis, and secretion of antimicrobial peptides. Thus, the lack of VDR in Paneth cells favors inflammation and susceptibility to infections in animal models $[44,84]$. Intestinal epithelial VDR down-regulates the expressions of ATG16L1, an IBD susceptibility gene involved in autophagy [44]. The production of lysozyme [44] and other antimicrobial peptides, such as defensin 4 [84] are reduced in VDR KO mice. Interestingly, microbiota alterations can be partially reversed by the administration of $1,25(\mathrm{OH}) \mathrm{D}$ [85]. High concentrations of vitamin D are related to increased serum cathelicidin and reduced inflammation in UC patients. Furthermore, vitamin D improves the cathelicidin antimicrobial activity in vitro against E. coli and protects against experimental colitis in vivo [86]. Conversely, the role of bacteria in modulating vitamin D levels and possible feedback interactions have been assessed by a few studies only, but it is widely accepted that commensal and pathogenic bacteria regulate VDR expression in animal models [33]. VDR signaling is indeed influenced by bacterial-produced metabolites, similar to butyrate, which is associated with increased epithelial VDR levels, in mice [44]. In turn butyrate, besides representing a primary energy substrate for colonic mucosal cells, increases the intermolecular cross-linking of fibrin chains transglutaminase- and non-transglutaminasemediated healing processes [87]. Lithocholic acid, another intraluminal compound derived from bacterial metabolism, suppresses IL-2 production by inducing VDR signaling in T cells [88]. Interestingly, some bacterial enzymes hydroxylate steroids, and process and activate vitamin D [89]. The microbiota also influences vitamin D metabolism through fibroblast growth factor (FGF)-23 and the regulation of CYP27B1 [90]. Only a few studies evaluated the effect of vitamin D on the microbiota in UC and CD patients. Vitamin D shows a positive effect in both CD and UC patients increasing Enterobacteriaceae and reducing overall intestinal inflammation [91-93]. Vitamin D administration (40,000 IU, once weekly) over 8 weeks did not induce changes in alpha diversity, despite a small reduction in Ruminococcus gnavus in a small cohort of UC patients [91]. The increased level of Enterobacteriaceae was not paralleled by the significant change in E. coli and invasive Fusobacterium nucleatum. In another study, vitamin D supplementation (300,000 IU in 4 weeks) modified the gut microbiota composition in CD patients in remission, with a transient increase of beneficial bacteria such as Alistipes, Roseburia, Parabacteroides, and Faecalibacterium. No changes were noted in vitamin D deficient healthy controls. The role of vitamin D supplementation in active CD was not investigated [93]. A possible connection between the seasonal levels of serum vitamin $\mathrm{D}$ levels and microbiome changes was also explored [94]. Increased concentrations of Pediococcus spp., Clostridium spp., and Escherichia/Shigella spp., associated with the highest vitamin D levels $(37.26 \mathrm{ng} / \mathrm{mL})$ were present in summer/autumn, while Eggerthella lenta, Helicobacter spp., Fusobacterium spp., and Faecalibacterium prausnitzii were relatively less represented. 


\section{Vitamin D Supplementation and Disease Course}

Hard evidence shows that mean vitamin D concentrations are lower in IBD patients than in the general population [14]. Independent predictors of vitamin D deficiency include non-Caucasian ethnicity, high BMI $\left(>30 \mathrm{~kg} / \mathrm{m}^{2}\right)$ both in CD and UC, and IBD-related surgery in CD $[95,96]$. Inadequate exposure to sunlight, more so in patients with active disease, negatively affects vitamin $\mathrm{D}$ levels. The use of cholestyramine to treat bile acid diarrhea following distal ileum resection, also contributes to vitamin $\mathrm{D}$ deficiency, due to malabsorption of fat-soluble vitamins [97]. Conversely, the multivariate analysis does not show an association of steroid use with vitamin D deficiency, in IBD ( $p=0.12$ versus controls) [95]. Nonetheless, international guidelines support vitamin D supplementation in all IBD patients on steroids, to prevent the negative effect of steroids on bone metabolism [27]. A correlation between vitamin $\mathrm{D}$ levels and disease activity is also present [30]. Levels of $25(\mathrm{OH}) \mathrm{D} \leq 25 \mathrm{ng} / \mathrm{mL}$ in a retrospective study had an AUC of $0.79-0.81$ for the identification of endoscopic and histologic activity [98]. Reduced risk of postoperative endoscopic recurrence in patients with CD who underwent surgery has been reported in an observational study in patients with vitamin D > $30 \mathrm{ng} / \mathrm{mL}$ (OR 0.22, 95\% CI 0.07-0.66, $p=0.006$ ) [99]. Thus, vitamin $\mathrm{D}$ has been proposed as a potential biomarker of disease activity $[98,100]$. This is, at best, debatable, as vitamin $\mathrm{D}$ concentration reflects changes occurring over relatively long periods. Whether vitamin D supplementation represents a potential therapeutic option is controversial [100]. A well-conducted RCT including 94 CD patients, showed a non-significantly lower rate of relapse in patients treated with $1200 \mathrm{IU} /$ day of vitamin $\mathrm{D}$ compared to the placebo group (6/46 vs. 14/48; $p=0.06$ ) [92]. However, several other RCTs led to conflicting conclusions. This likely results from the small number of patients included in underpowered studies (Table 1). Moreover, the extreme variability in dosage regimens, and duration of follow-up, make results hardly comparable. 
Table 1. RCTs evaluating vitamin D supplementation on IBD and clinical course.

\begin{tabular}{|c|c|c|c|c|c|c|c|c|c|c|c|c|}
\hline STUDY & Country & $\begin{array}{l}\text { Patients } \\
\text { Included }\end{array}$ & Disease & $\begin{array}{l}\text { Intervention } \\
\text { Group }\end{array}$ & $\begin{array}{l}\text { Vitamin D } \\
\text { Doses in } \\
\text { the Inter- } \\
\text { vention } \\
\text { Group }\end{array}$ & $\begin{array}{l}\text { Control } \\
\text { Group }\end{array}$ & $\begin{array}{c}\text { Control } \\
\text { Group } \\
\text { (Placebo or } \\
\text { VitD) }\end{array}$ & $\begin{array}{l}\text { Difference } \\
\text { in the } \\
\text { Mean } \\
\text { Daily Dose } \\
*\end{array}$ & Follow-Up & $\begin{array}{l}\text { Outcomes } \\
\text { (Disease } \\
\text { Activity } \\
\text { Evalua- } \\
\text { tion) }\end{array}$ & $\begin{array}{l}\text { Outcomes } \\
\text { (Adverse } \\
\text { Events; } \\
\text { Vitamin D } \\
\text { Levels) }\end{array}$ & $\begin{array}{l}\text { Relapse In- } \\
\text { tervention } \\
\text { vs. Control }\end{array}$ \\
\hline $\begin{array}{l}\text { Bafutto } \\
2017 \text { [101] }\end{array}$ & Brazil & $\begin{array}{c}30 \\
\text { moderate to } \\
\text { severe and } \\
\text { VitD levels } \\
<30 \mathrm{ng} / \mathrm{mL}\end{array}$ & $\mathrm{CD}$ & 20 & $\begin{array}{c}50,000 \\
\text { IU/die } \\
10.000 \\
\text { IU/die }\end{array}$ & 10 & 2000 UI/die & $\begin{array}{l}48,000 \mathrm{IU} \\
8000 \mathrm{IU}\end{array}$ & 8 weeks & $\begin{array}{c}\downarrow \mathrm{CRP} ; \downarrow \text { FC; } \\
\uparrow \mathrm{IBDQ}\end{array}$ & $\uparrow \mathrm{VitD}$ & n.a. \\
\hline $\begin{array}{l}\text { Ahamed } \\
2019 \text { [102] }\end{array}$ & India & $\begin{array}{c}60 \text { with } \\
\text { UCDAI >3 } \\
\text { and VitD } \\
\text { levels }<40 \\
\text { ng } / \mathrm{mL}\end{array}$ & UC & 30 & $\begin{array}{c}60,000 \mathrm{IU} / \mathrm{d} \\
\text { for } 8 \text { days }\end{array}$ & 30 & placebo & $17,142 \mathrm{IU}$ & 4 weeks & $\begin{array}{l}\downarrow \text { UCDAI; } \\
\downarrow \text { CRP; } \downarrow \text { FC }\end{array}$ & $\uparrow \mathrm{VitD} ;=\mathrm{AE}$ & n.a. \\
\hline $\begin{array}{c}\text { Narula } \\
2017 \text { [103] }\end{array}$ & Canada & $\begin{array}{l}34 \text { in } \\
\text { remission }\end{array}$ & $\mathrm{CD}$ & 18 & $\begin{array}{l}\text { 10,000 } \\
\text { IU/die }\end{array}$ & 16 & $1000 \mathrm{IU} / \mathrm{die}$ & $9000 \mathrm{IU}$ & 12 months & $\begin{array}{c}=\mathrm{CRP} ; \\
\downarrow \text { relapse }\end{array}$ & $\uparrow \mathrm{VitD} ;=\mathrm{AE}$ & 0 vs. $3^{* *}$ \\
\hline $\begin{array}{c}\text { Dadaei } \\
2015 \text { [104] }\end{array}$ & Ireland & $\begin{array}{c}108 \text { and } \\
\text { VitD levels } \\
<30 \mathrm{ng} / \mathrm{mL}\end{array}$ & IBD & $\begin{array}{l}53 \text { (10 CD; } \\
\text { 43UC) }\end{array}$ & $50,000 /$ week & $\begin{array}{c}55 \text { (6 CD; } \\
49 \mathrm{UC})\end{array}$ & placebo & 7142 UI & 12 weeks & none & $\uparrow \mathrm{VitD}$ & n.a. \\
\hline $\begin{array}{c}\text { de Bruyn } \\
2021^{* *} \\
{[105]}\end{array}$ & $\begin{array}{l}\text { Netherlands } \\
\text { and } \\
\text { Belgium }\end{array}$ & $\begin{array}{l}143 \text { with } \\
\text { ileocolonic } \\
\text { resection }\end{array}$ & $\mathrm{CD}$ & 72 & 25,000/week & 71 & placebo & $3571 \mathrm{UI}$ & 26 weeks & $\begin{array}{c}\text { = Rutgerts } \\
\text { score; } \\
\text { =IBDQ; } \\
=\mathrm{CRP} ;=\mathrm{FC}\end{array}$ & $\uparrow \mathrm{VitD} ;=\mathrm{AE}$ & n.a. \\
\hline $\begin{array}{c}\text { Sharifi } \\
2016 \text { [106] }\end{array}$ & Iran & $\begin{array}{l}86 \text { in } \\
\text { remission }\end{array}$ & UC & 46 & $\begin{array}{l}300,000 \\
\text { IU/90 die }\end{array}$ & 40 & placebo & $3300 \mathrm{IU}$ & 3 months & $\begin{array}{l}\downarrow \text { ESR; } \\
\downarrow \text { CRP }\end{array}$ & $\uparrow \mathrm{VitD}$ & n.a. \\
\hline $\begin{array}{l}\text { Mathur } \\
2017 \text { [107] }\end{array}$ & U.S.A. & $\begin{array}{l}18 \text { and VitD } \\
<30 \mathrm{ng} / \mathrm{mL}\end{array}$ & UC & 10 & $4000 \mathrm{IU} / \mathrm{die}$ & 8 & $2000 \mathrm{IU} / \mathrm{die}$ & $2000 \mathrm{IU}$ & 3 months & $\begin{array}{l}\text { =CRP; } \\
=\text { pMayo; } \\
\uparrow S I B D Q\end{array}$ & $\uparrow \mathrm{VitD} ;=\mathrm{AE}$ & n.a. \\
\hline $\begin{array}{l}\text { Raftery } \\
2015 \text { [54] }\end{array}$ & Ireland & $\begin{array}{l}27 \text { in } \\
\text { remission }\end{array}$ & $\mathrm{CD}$ & 13 & $2000 \mathrm{IU} / \mathrm{die}$ & 14 & placebo & $2000 \mathrm{IU}$ & 3 months & $\begin{array}{c}=\mathrm{CDAI} ; \\
=\mathrm{CRP} ;=\mathrm{FC} ; \\
=\mathrm{QoL}\end{array}$ & $\uparrow \mathrm{VitD}$ & 0 vs. 0 \\
\hline
\end{tabular}


Table 1. Cont.

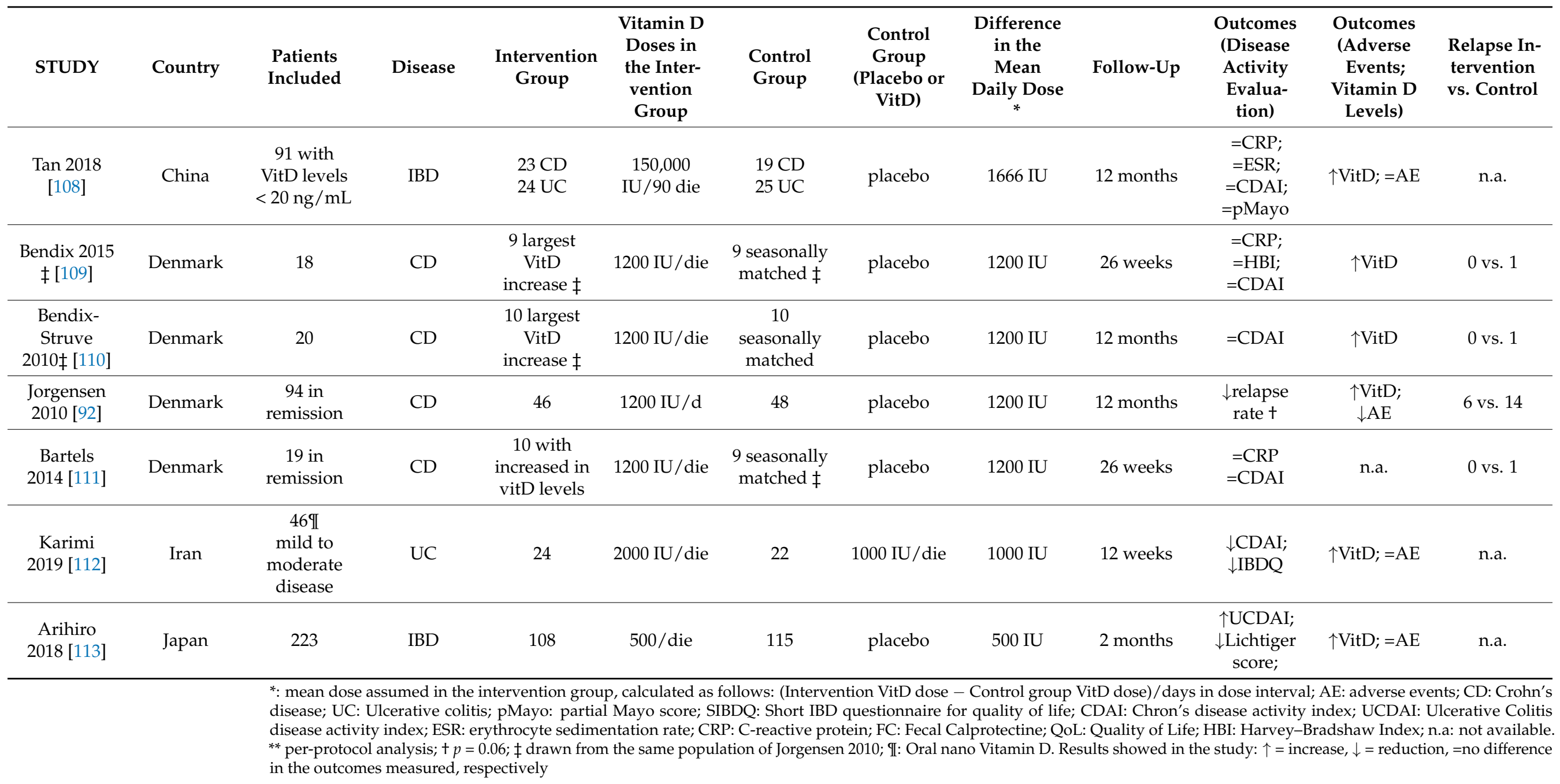


In a prospective study, Garg et al [114] used higher doses of vitamin D than other RCTs. In the trial, 10.000 IU of vitamin D was daily provided to 10 IBD patients. The dose was then adjusted over 12 weeks to achieve the target of 40-50 ng/mL of serum vitamin D. A significant reduction in clinical activity score was observed both in CD and UC patients [114]. Conversely, another RCT carried out in 27 CD patients in remission, treated with $2000 \mathrm{UI} / \mathrm{d}$ or placebo, showed no difference in CRP, FC, CDAI, and QoL. However, the sub-group analysis of those subjects achieving $25(\mathrm{OH}) \mathrm{D}$ concentrations of $>75 \mathrm{nmol} / \mathrm{L}$ $(\mathrm{n}=18)$ compared to those who did not $(\mathrm{n}=9)$, documented significantly lower CRP, higher QoL, and a non-significantly lower CDAI in those with higher vitamin D levels [54]. All available RCT data were pooled in three meta-analyses [115-117]. Two of them reported that Vitamin D supplementation, as expected, improves the serum levels of the vitamin. It also ameliorates clinical and biochemical disease activity scores [115,116]. Conversely, the meta-analysis carried out by Guo did not confirm a decrease in disease activity indexes, despite some decrease in C-reactive protein (CRP) levels [117]. In the subgroup analysis including only observational studies by Guzman-Pardo, the Harvey Bradshaw Index improved by -1.47 points $(95 \% \mathrm{CI},-2.47$ to $-0.47, p=0.004, \mathrm{I} 2=0 \%)$ in CD patients, and high sensitivity CRP decreased in all sub-groups [115]. On the other hand, a sub-group analysis including four RCTs that evaluated the changes in CDAI scores following vitamin $\mathrm{D}$ administration did not statistically differ from controls. [115]. Therapeutic efficacy in active disease is still unclear, but vitamin D supplementation has been reported to reduce the relapse rate, irrespective of the duration of follow-up, or dosage [116]. The importance of adequate levels of vitamin $\mathrm{D}$ is supported by observations in IBD patients treated with biologics. Normal vitamin D levels at induction with anti-TNF- $\alpha$ are associated with 2.64 increased odds of remission at 3 months compared to patients with low vitamin D levels (OR 2.64, 95\% CI 1.31-5.32, $p=0.0067$ ) [118]. Vitamin D $\leq 25 \mathrm{ng} / \mathrm{mL}$ identified patients $(6 / 6)$ losing response to biological drugs $(6 / 50)$ [98]. The same holds for an increased risk of primary non-response to vedolizumab (OR 26.10, 95\% CI 14.30-48.90, $p<0.001$ ) and failure at 1-year follow-up (OR 6.10, 95\% CI 3.06-12.17, $p<0.001$ ) [119]. Overall, a role for vitamin $\mathrm{D}$ supplementation in the therapeutic management of IBD with direct effects on intestinal function is supported by available data (Figure 3).

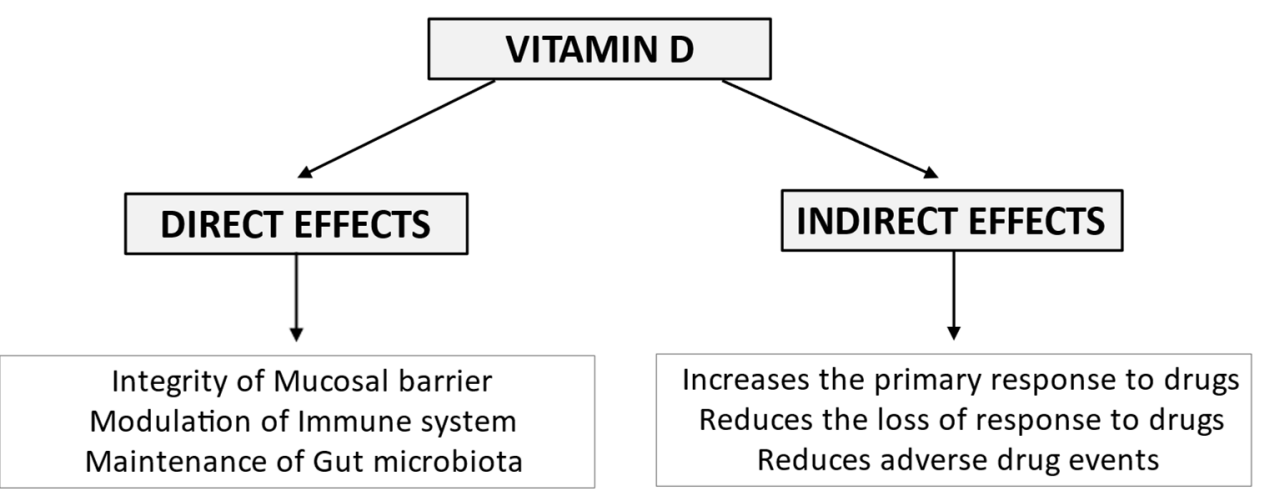

Figure 3. Vitamin D exerts its biological effects on the intestine in IBD maintaining mucosal barrier integrity, modulating the immune system and the composition of the gut microbiota. Emerging evidence suggests that vitamin D deficiency may unfavorably affect response to biological therapy, being associated with an increased risk of both primary non-response and secondary loss of response to the drugs. Furthermore, vitamin D deficiency may worsen corticosteroid-related osteopenia/osteoporosis and increase the risk of immunomodulator-related infections.

Less clear are the mechanisms indirectly relating vitamin D levels, or supplementation, and the therapeutic response to biological drugs. Heterogeneity in the study design, including dosage and length of intervention, as well as the small series of patients, prevent reliable conclusions (Table 2). More RCTs with adequate size and well-defined protocols are needed. 
Table 2. Main limitations of the available studies.

\begin{tabular}{c}
\hline Different populations \\
- Age \\
-Ethnicity \\
-Country \\
-Sun exposure \\
-Comorbidities \\
\hline Small number of patients \\
\hline Partial data according to \\
-Disease subtype \\
-Disease progression \\
-Medical treatment \\
-IBD-related surgery \\
-Dietary pattern \\
\hline Limited data on changes in disease activity \\
\hline Different vitamin D dosage regimens and treatment duration
\end{tabular}

\section{Conclusions}

Vitamin D plays an important role in maintaining intestinal homeostasis and mucosal barrier integrity, besides modulating the inflammatory immune response and the composition of gut microbiota. All these mechanisms are potentially related to the development of IBD, and some evidence suggests an influence on disease occurrence, relapse, and clinical course. Preclinical data suggest that vitamin D/VDR signaling regulates the expression of several components of tight junctions and adherens junctions, favoring the integrity of the mucosal barrier. Although the direct role of vitamin D levels on mucus production has not been documented, indirect modulation is likely.

Vitamin D regulates immunity through direct inhibition of Th1/Th17 cells, or indirectly inducing IL-10-producing regulatory T cells. It also activates specialized cells like Paneth cells in the epithelium and promotes the expression of antimicrobial peptides. Some effects have also been described on NK cells. Vitamin D has been recently linked to changes in intestinal bacterial composition. As the microbiota does not express VDR, the effects of vitamin D on intestinal flora are supposedly mediated by epithelial and immune cells. Bidirectional effects are present, resulting from VDR functions modulated by microbial metabolites, such as butyrate. However, most studies report short-term experiments, and what happens over a long time is yet to be defined. Most data trying to elucidate the molecular mechanisms of action of vitamin $\mathrm{D}$ derived from studies carried out in a preclinical setting, hampering the translation of results to IBD patients. Indeed, the effects of vitamin $\mathrm{D} / \mathrm{VDR}$ signaling in murine models indicate that following vitamin $\mathrm{D}$ administration the severity of chemically induced colitis is reduced and mucosal healing processes are more effective. Vitamin D deficiency in IBD is multifactorial, resulting from inadequate sun exposure, unnecessary dietary restrictions, and, in some instances, impaired absorption of nutrients. It is significantly more common in IBD compared to the general population with potentially relevant clinical implications. Whether vitamin D shortage results from active, long-standing disease, or represents itself a factor favoring inflammation is still to be defined. Emerging evidence, however, suggests that vitamin D deficiency may be implicated in more aggressive disease behavior and impaired response to biological therapy. If this proves true a therapeutic effect of vitamin D supplementation may be anticipated. Nonetheless, high-quality interventional RCT with an adequate baseline assessment and follow-up documenting laboratory and endoscopic improvement following vitamin D administration is still lacking. This leads however to a crucial unsettled point. A universally accepted definition of vitamin D deficiency/insufficiency (optimal blood levels) in IBD is still undefined, as the presently used normal range derives from studies centered on bone metabolism. The circulating levels required for disease prevention and management of IBD 
still need to be defined, as well as the optimal dosage for replacement and its duration. The vitamin D/VDR pathway represents however a promising area for further research, and a better understanding of its functions may lead to novel therapeutic strategies.

Author Contributions: F.V., M.V., S.L. and N.C. performed the literature review, wrote the manuscript, and prepared the Figures; A.V. and G.L. reviewed the manuscript and provided critical comments; G.L. suggested the topic of the review and supervised, wrote, and critically reviewed the manuscript. All authors have read and agreed to the published version of the manuscript.

Funding: This research received no external funding.

Institutional Review Board Statement: Not applicable.

Informed Consent Statement: Not applicable.

Data Availability Statement: Not applicable.

Acknowledgments: Not applicable.

Conflicts of Interest: The authors declare no conflict of interest.

\section{References}

1. Lamberg-Allardt, C. Vitamin D in foods and as supplements. Prog. Biophys. Mol. Biol. 2006, 92, 33-38. [CrossRef]

2. Bakke, D.; Sun, J. Ancient nuclear receptor VDR with new functions: Microbiome and inflammation. Inflamm. Bowel Dis. 2018, 24, 1149-1154. [CrossRef] [PubMed]

3. Chirumbolo, S.; Bjørklund, G.; Sboarina, A.; Vella, A. The role of vitamin D in the immune system as a pro-survival molecule. Clin. Ther. 2017, 39, 894-916. [CrossRef] [PubMed]

4. $\quad$ Clemens, T.L.; Adams, J.S.; Henderson, S.L.; Holick, M.F. Increased skin pigment reduces the capacity of skin to synthesize vitamin D3. Lancet 1982, 1, 74-76. [CrossRef]

5. Prosser, D.E.; Jones, G. Enzymes involved in the activation and inactivation of vitamin D. Trends Biochem. Sci. 2004, 29, 664-673. [CrossRef]

6. Jones, G.; Prosser, D.E.; Kaufmann, M. Cytochrome P450-mediated metabolism of vitamin D. J. Lipid Res. 2014, 55, 13-31. [CrossRef]

7. Ross, A.C.; Manson, J.E.; Abrams, S.A.; Aloia, J.F.; Brannon, P.M.; Clinton, S.K.; Durazo-Arvizu, R.A.; Gallagher, J.C.; Gallo, R.L.; Jones, G.; et al. The 2011 Report on Dietary Reference Intakes for Calcium and Vitamin D From the Institute of Medicine: What Clinicians Need to Know. Obstet. Gynecol. 2011, 66, 356-357. [CrossRef]

8. Holick, M.F.; Binkley, N.C.; Bischo-Ferrari, H.A.; Gordon, C.M.; Hanley, D.A.; Heaney, R.P.; Murad, M.H.; Weaver, C.M. Evaluation, Treatment, and Prevention of Vitamin D Deficiency: An Endocrine Society Clinical Practice Guideline. J. Clin. Endocrinol. Metab. 2011, 96, 1911-1930. [CrossRef] [PubMed]

9. World Health Organisation. Prevention and management of osteoporosis. World Health Organ Tech. Rep. Ser. 2003, 921, 1-164.

10. Larose, T.L.; Chen, Y.; Camargo, C.A.; Langhammer, A.; Romundstad, P.; Mai, X.M. Factors associated with vitamin D deficiency in a Norwegian population: The HUNT Study. J. Epidemiol. Commun. Health 2014, 68, 165-170. [CrossRef]

11. Hypponen, E.; Power, C. Hypovitaminosis D in British adults at age $45 \mathrm{y}$ : Nationwide cohort study of dietary and lifestyle predictors. Am. J. Clin. Nutr. 2007, 85, 860-868. [CrossRef] [PubMed]

12. Palacios, C.; Gonzalez, L. Is vitamin D deficiency a major global public health problem? J. Steroid Biochem. Mol. Biol. 2014, 144, 138-145. [CrossRef]

13. Burrelli Scotti, G.; Afferri, M.T.; De Carolis, A.; Vaiarello, V.; Fassino, V.; Ferrone, F.; Minisola, S.; Nieddu, L.; Vernia, P. Factors affecting vitamin D deficiency in active inflammatory bowel diseases. Dig. Liver Dis. 2019, 51, 657-662. [CrossRef]

14. Del Pinto, R.; Pietropaoli, D.; Chandar, A.K.; Ferri, C.; Cominelli, F. Association Between Inflammatory Bowel Disease and Vitamin D Deficiency: A Systematic Review and Meta-analysis. Inflamm. Bowel Dis. 2015, 21, 2708-2717. [CrossRef]

15. Vernia, P.; Burrelli Scotti, G.; Dei Giudici, A.; Chiappini, A.; Cannizzaro, S.; Afferri, M.T.; de Carolis, A. Inadequate sunlight exposure in patients with inflammatory bowel disease. J Dig Dis. 2018, 19, 8-14. [CrossRef] [PubMed]

16. Fletcher, J. Vitamin D deficiency in patients with inflammatory bowel disease. Br. J. Nurs. 2016, 25, 846-851. [CrossRef] [PubMed]

17. Schulte, C.; Dignass, A.U.; Mann, K.; Goebell, H. Reduced bone mineral density and unbalanced bone metabolism in patients with inflammatory bowel disease. Inflamm. Bowel Dis. 1998, 4, 268-275. [CrossRef]

18. Ott, C.; Scholmerich, J. Extraintestinal manifestations and complications in IBD. Nat. Rev. Gastroenterol. Hepatol. 2013, 10, 585-595. [CrossRef] [PubMed]

19. Szafors, P.; Che, H.; Barnetche, T.; Morel, J.; Gaujoux-Viala, C.; Combe, B.; Lukas, C. Risk of fracture and low bone mineral density in adults with inflammatory bowel diseases. A systematic literature review with meta-analysis. Osteoporos. Int. 2018, 29, 2389-2397. [CrossRef]

20. Komaki, Y.; Komaki, F.; Micic, D.; Ido, A.; Sakuraba, A. Risk of fractures in inflammatory bowel diseases: A systematic review and meta-analysis. J. Clin. Gastroenterol. 2018, 52, 796-804. [CrossRef] [PubMed] 
21. Saxena, Y.; Routh, S.; Mukhopadhaya, A. Immunoporosis: Role of Innate Immune Cells in Osteoporosis. Front. Immunol. 2021, 12, 687037. [CrossRef]

22. Chedid, V.G.; Kane, S.V. Bone Health in Patients with Inflammatory Bowel Diseases. J. Clin. Densitom. 2020, $23,182-189$. [CrossRef] [PubMed]

23. Torres, J.; Bonovas, S.; Doherty, G.; Kucharzik, T.; Gisbert, J.P.; Raine, T.; Adamina, M.; Armuzzi, A.; Bachmann, O.; Bager, P.; et al. ECCO Guidelines on Therapeutics in Crohn's Disease: Medical Treatment. J. Crohns. Colitis. 2020, 14, 4-22. [CrossRef] [PubMed]

24. Raine, T.; Bonovas, S.; Burisch, J.; Kucharzik, T.; Adamina, M.; Annese, V.; Bachmann, O.; Bettenworth, D.; Chaparro-Sanchez, M.; Czuber-Dochan, W.; et al. ECCO Guidelines on Therapeutics in Ulcerative Colitis: Medical Treatment. J. Crohns. Colitis. 2021, 12, jjab178. [CrossRef]

25. Lichtenstein, G.R.; Loftus, E.V.; Isaacs, K.L.; Regueiro, M.D.; Gerson, L.B.; Sands, B. ACG Clinical Guideline: Management of Crohn's Disease in Adults. Am. J. Gastroenterol. 2018, 113, 481-517. [CrossRef]

26. Rubin, D.T.; Ananthakrishnan, A.N.; Siegel, C.A.; Sauer, B.G.; Long, M.D. ACG Clinical Guideline: Ulcerative Colitis in Adults. Am. J. Gastroenterol. 2019, 114, 384-413. [CrossRef]

27. Magro, F.; Gionchetti, P.; Eliakim, R.; Ardizzone, S.; Armuzzi, A.; Barreiro-de Acosta, M.; Burisch, J.; Gecse, K.B.; Hart, A.L.; Hindryckx, P.; et al. European Crohn's and Colitis Organisation [ECCO]. Third European Evidence-based Consensus on Diagnosis and Management of Ulcerative Colitis. Part 1: Definitions, Diagnosis, Extra-intestinal Manifestations, Pregnancy, Cancer Surveillance, Surgery, and Ileo-anal Pouch Disorders. J. Crohns. Colitis. 2017, 11, 649-670. [CrossRef]

28. Wang, Y.; Zhu, J.; DeLuca, H.F. Where is the vitamin D receptor? Arch. Biochem. Biophys. 2012, 523, 123-133. [CrossRef]

29. Zhu, W.; Yan, J.; Zhi, C.; Zhou, Q.; Yuan, X. 1,25(OH $)_{2} \mathrm{D}_{3}$ deficiency-induced gut microbial dysbiosis degrades the colonic mucus barrier in Cyp27b1 knockout mouse model. Gut Pathog. 2019, 11, 8. [CrossRef] [PubMed]

30. Gubatan, J.; Chou, N.D.; Nielsen, O.H.; Moss, A.C. Systematic review with meta-analysis: Association of vitamin D status with clinical outcomes in adult patients with inflammatory bowel disease. Aliment. Pharmacol. Ther. 2019, 50, 1146-1158. [CrossRef] [PubMed]

31. van der Post, S.; Jabbar, K.S.; Birchenough, G.; Arike, L.; Akhtar, N.; Sjovall, H.; Johansson, M.E.; Hansson, G.C. Structural weakening of the colonic mucus barrier is an early event in ulcerative colitis pathogenesis. Gut 2019, 68, 2142-2151. [CrossRef]

32. Liu, W.; Chen, Y.; Golan, M.A.; Annunziata, M.L.; Du, J.; Dougherty, U.; Kong, J.; Much, M.; Huang, Y.; Pekow, J. Intestinal epithelial vitamin D receptor signaling inhibits experimental colitis. J. Clin. Investig. 2013, 123, 3983-3996. [CrossRef]

33. Wu, S.; Liao, A.P.; Xia, Y.; Li, Y.C.; Li, J.D.; Sartor, R.B.; Sun, J. Vitamin D receptor negatively regulates bacterial-stimulated NF-кB activity in intestine. Am. J. Pathol. 2010, 177, 686-697. [CrossRef] [PubMed]

34. Domazetovic, V.; Iantomasi, T.; Bonanomi, A.G.; Stio, M. Vitamin D regulates claudin-2 and claudin-4 expression in active ulcerative colitis by p-Stat-6 and Smad-7 signaling. Int. J. Colorectal Dis. 2020, 35, 1231-1242. [CrossRef] [PubMed]

35. Chen, S.W.; Wang, P.Y.; Zhu, J.; Chen, G.W.; Zhang, J.I.; Chen, Z.Y.; Zuo, S.; Liu, Y.C.; Pan, Y.S. Protective effect of 1,25dihydroxyvitamin $\mathrm{d} 3$ on lipopolysaccharide-induced intestinal epithelial tight junction injury in caco-2 cell. Monolayers. Inflammation. 2015, 38, 375-383. [CrossRef] [PubMed]

36. Du, J.; Chen, Y.; Shi, Y.; Liu, T.; Cao, Y.; Tang, Y.; Ge, X.; Nie, H.; Zheng, C.; Li, Y.C. 1,25-Dihydroxyvitamin D protects intestinal epithelial barrier by regulating the myosin light chain kinase signaling pathway. Inflamm. Bowel. Dis. 2015, 21, 2495-2506. [CrossRef] [PubMed]

37. Riner, K.; Boos, A.; Hässig, M.; Liesegang, A. Vitamin D receptor distribution in intestines of domesticated sheep Ovis ammon $\mathrm{f}$. aries. J. Morphol. 2008, 269, 144-152. [CrossRef] [PubMed]

38. Paz, H.B.; Tisdale, A.S.; Danjo, Y.; Spurr-Michaud, S.J.; Argüeso, P.; Gipson, I.K. The role of calcium in mucin packaging within goblet cells. Exp. Eye Res. 2003, 77, 69-75. [CrossRef]

39. Mandle, H.B.; Jahan, F.A.; Bostick, R.M.; Baron, J.A.; Barry, E.L.; Yacoub, R.; Merrill, J.; Rutherford, R.E.; Seabrook, M.E.; Fedirko, V. Effects of supplemental calcium and vitamin D on tight-junction proteins and mucin-12 expression in the normal rectal mucosa of colorectal adenoma patients. Mol. Carcinog. 2019, 58, 1279-1290. [CrossRef] [PubMed]

40. Gaudier, E.; Jarry, A.; Blottière, H.M.; de Coppet, P.; Buisine, M.P.; Aubert, J.P.; Laboisse, C.; Cherbut, C.; Hoebler, C. Butyrate specifically modulates MUC gene expression in intestinal epithelial goblet cells deprived of glucose. Am. J. Physiol. Gastrointest. Liver Physiol. 2004, 287, G1168-G1174. [CrossRef] [PubMed]

41. Du, J.; Wei, X.; Ge, X.; Chen, Y.; Li, Y.C. Microbiota-dependent induction of colonic CYP27B1 is associated with colonic inflammation: Implications of locally produced 1,25-dihydroxyvitamin D3 in inflammatory regulation in the colon. Endocrinology 2017, 158, 4064-4075. [CrossRef]

42. Lagishetty, V.; Misharin, A.V.; Liu, N.Q.; Lisse, T.S.; Chun, R.F.; Ouyang, Y.; McLachlan, S.M.; Adams, J.S.; Hewison, M. Vitamin D deficiency in mice impairs colonic antibacterial activity and predisposes to colitis. Endocrinology 2010, 151, 2423-2432. [CrossRef]

43. Assa, A.; Vong, L.; Pinnell, L.J.; Avitzur, N.; Johnson-Henry, K.C.; Sherman, P.M. Vitamin D deficiency promotes epithelial barrier dysfunction and intestinal inflammation. J. Infect. Dis. 2014, 210, 1296-1305. [CrossRef]

44. Wu, S.; Zhang, Y.G.; Lu, R.; Xia, Y.; Zhou, D.; Petrof, E.O.; Claud, E.C.; Chen, D.; Chang, E.B.; Carmeliet, G. Intestinal epithelial vitamin D receptor deletion leads to defective autophagy in colitis. Gut 2015, 64, 1082-1094. [CrossRef]

45. Froicu, M.; Weaver, V.; Wynn, T.A.; McDowell, M.A.; Welsh, J.E.; Cantorna, M.T. A crucial role for the vitamin D receptor in experimental inflammatory bowel diseases. Mol. Endocrinol. 2003, 17, 2386-2392. [CrossRef] 
46. Kühne, H.; Hause, G.; Grundmann, S.M.; Schutkowski, A.; Brandsch, C.; Stangl, G.I. Vitamin D receptor knockout mice exhibit elongated intestinal microvilli and increased ezrin expression. Nutr. Res. 2016, 36, 184-192. [CrossRef]

47. Kim, J.H.; Yamaori, S.; Tanabe, T.; Johnson, C.H.; Krausz, K.W.; Kato, S.; Gonzalez, F.J. Implication of intestinal VDR deficiency in inflammatory bowel disease. Biochim. Biophys. Acta Gen. Subj. 2013, 1830, 2118-2128. [CrossRef] [PubMed]

48. Reynolds, C.J.; Koszewski, N.J.; Horst, R.L.; Beitz, D.C.; Goff, J.P. Localization of the 1,25-dihydroxyvitamin d-mediated response in the intestines of mice. J. Steroid Biochem. Mol. Biol. 2019, 186, 56-60. [CrossRef]

49. Zhang, Y.G.; Lu, R.; Xia, Y.; Zhou, D.; Petrof, E.; Claud, E.C.; Sun, J. Lack of vitamin D receptor leads to hyperfunction of claudin-2 in intestinal inflammatory responses. Inflamm. Bowel Dis. 2019, 25, 97-110. [CrossRef]

50. Garg, M.; Royce, S.G.; Tikellis, C.; Shallue, C.; Sluka, P.; Wardan, H.; Hosking, P.; Monagle, S.; Thomas, M.; Lubel, J.S.; et al. The intestinal vitamin D receptor in inflammatory bowel disease: Inverse correlation with inflammation but no relationship with circulating vitamin D status. Therap. Adv. Gastroenterol. 2019, 12, 1-15. [CrossRef]

51. Abreu-Delgado, Y.; Isidro, R.A.; Torres, E.A.; González, A.; Cruz, M.L.; Isidro, A.A.; González-Keelan, C.I.; Medero, P.; Appleyard, C.B. Serum vitamin D and colonic vitamin D receptor in inflammatory bowel disease. World J. Gastroenterol. 2016, 22, 3581-3591. [CrossRef] [PubMed]

52. Chen, Y.; Du, J.; Zhang, Z.; Liu, T.; Shi, Y.; Ge, X.; Li, Y.C. MicroRNA-346 mediates tumor necrosis factor $\alpha$-induced downregulation of gut epithelial vitamin D receptor in inflammatory bowel diseases. Inflamm. Bowel Dis. 2014, 20, 1910-1918. [CrossRef]

53. Fujita, H.; Sugimoto, K.; Inatomi, S.; Maeda, T.; Osanai, M.; Uchiyama, Y.; Yamamoto, Y.; Wada, T.; Kojima, T.; Yokozaki, H. Tight junction proteins claudin-2 and-12 are critical for vitamin D-dependent Ca2+ absorption between enterocytes. Mol. Biol. Cell 2008, 19, 1912-1921. [CrossRef] [PubMed]

54. Raftery, T.; Martineau, A.R.; Greiller, C.L.; Ghosh, S.; McNamara, D.; Bennett, K.; Meddings, J.; O'Sullivan, M. Effects of vitamin D supplementation on intestinal permeability, cathelicidin and disease markers in Crohn's disease: Results from a randomised double-blind placebo-controlled study. Un. Eur. Gastroenterol. J. 2015, 3, 294-302. [CrossRef]

55. Qiu, W.; Wu, B.; Wang, X.; Buchanan, M.E.; Regueiro, M.D.; Hartman, D.J.; Schoen, R.E.; Yu, J.; Zhang, L. PUMA-mediated intestinal epithelial apoptosis contributes to ulcerative colitis in humans and mice. J. Clin. Investig. 2011, 121, 1722-1732. [CrossRef]

56. Kong, J.; Zhang, Z.; Much, M.W.; Ning, G.; Sun, J.; Hart, J.; Bissonnette, M.; Li, Y.C. Novel role of the vitamin D receptor in maintaining the integrity of the intestinal mucosal barrier. Am. J. Physiol. Gastrointestinal Liver Physiol. 2008, 294, G208-G216. [CrossRef]

57. Zhao, H.; Zhang, H.; Wu, H.; Li, H.; Liu, L.; Guo, J.; Li, C.; Shih, D.Q.; Zhang, X. Protective role of 1,25 (OH) 2 vitamin D 3 in the mucosal injury and epithelial barrier disruption in DSS-induced acute colitis in mice. BMC Gastroenterol. 2012, 12, 57. [CrossRef]

58. Cantorna, M.T.; Munsick, C.; Bemiss, C.; Mahon, B.D. 1,25-Dihydroxycholecalciferol prevents and ameliorates symptoms of experimental murine inflammatory bowel disease. J. Nutr. 2000, 130, 2648-2652. [CrossRef]

59. Lin, Y.D.; Arora, J.; Diehl, K.; Bora, S.A.; Cantorna, M.T. Vitamin D is required for ILC3 derived IL-22 and protection from Citrobacter rodentium infection. Front. Immunol. 2019, 10, 1. [CrossRef] [PubMed]

60. Mahon, B.D.; Wittke, A.; Weaver, V.; Cantorna, M.T. The targets of vitamin D depend on the differentiation and activation status of CD4 positive T cells. J. Cell Biochem. 2003, 89, 922-932. [CrossRef]

61. Hewison, M.; Burke, F.; Evans, K.N.; Lammas, D.A.; Sansom, D.M.; Liu, P.; Modlin, R.L.; Adams, J.S. Extra-renal 25hydroxyvitamin D3-1alpha-hydroxylase in human health and disease. J. Steroid Biochem. Mol. Biol. 2007, 103, 316-321. [CrossRef]

62. Liu, P.T.; Stenger, S.; Li, H.; Wenzel, L.; Tan, B.H.; Krutzik, S.R.; Ochoa, M.T.; Schauber, J.; Wu, K.; Meinken, C.; et al. Toll-like receptor triggering of a vitamin D-mediated human antimicrobial response. Science 2006, 311, 1770-1773. [CrossRef]

63. Kongsbak, M.; von Essen, M.R.; Boding, L.; Levring, T.B.; Schjerling, P.; Lauritsen, J.P.H.; Woetmann, A.; Ødum, N.; Bonefeld, C.M.; Meisler, C. Vitamin D up-regulates the vitamin D receptor by protecting it from proteasomal degradation in human CD4+ T cells. PLoS ONE 2014, 9, e96695. [CrossRef]

64. Ooi, J.H.; McDaniel, K.L.; Weaver, V.; Cantorna, M.T. Murine CD8+ T cells but not macrophages express the vitamin D 1alphahydroxylase. J. Nutr. Biochem. 2014, 25, 58-65. [CrossRef] [PubMed]

65. Sadeghi, K.; Wessner, B.; Laggner, U.; Ploder, M.; Tamandl, D.; Friedl, J.; Zügel, U.; Steinmeyer, A.; Pollak, A.; Roth, E.; et al. Vitamin D3 down-regulates monocyte TLR expression and triggers hyporesponsiveness to pathogen-associated molecular patterns. Eur. J. Immunol. 2006, 36, 361-370. [CrossRef] [PubMed]

66. Griffin, M.D.; Lutz, W.; Phan, V.A.; Bachman, L.A.; McKean, D.J.; Kumar, R. Dendritic cell modulation by 1alpha,25 dihydroxyvitamin D3 and its analogs: A vitamin D receptor-dependent pathway that promotes a persistent state of immaturity in vitro and in vivo. Proc. Natl. Acad. Sci. USA 2001, 98, 6800-6805. [CrossRef]

67. Verma, R.; Kim, J.Y. 1,25-Dihydroxyvitamin D3 Facilitates M2 Polarization and Upregulates TLR10 Expression on Human Microglial Cells. Neuroimmunomodulation 2016, 23, 75-80. [CrossRef]

68. Korf, H.; Wenes, M.; Stijlemans, B.; Takiishi, T.; Robert, S.; Miani, M.; Eizirik, D.L.; Gysemans, C.; Mathieu, C. 1,25Dihydroxyvitamin $\mathrm{D}(3)$ curtails the inflammatory and T cell stimulatory capacity of macrophages through an IL-10-dependent mechanism. Immunobiology 2012, 217, 1292-1300. [CrossRef] [PubMed]

69. Cantorna, M.T.; Snyder, L.; Lin, Y.D.; Yang, L. Vitamin D and 1,25(OH)2D regulation of T cells. Nutrients 2015, 7, 3011-3021. [CrossRef]

70. Mathieu, C.; Adorini, L. The coming of age of 1,25-dihydroxyvitamin $\mathrm{D}(3)$ analogs as immunomodulatory agents. Trends Mol. Med. 2002, 8, 174-179. [CrossRef] 
71. Waddell, A.; Zhao, J.; Cantorna, M.T. NKT cells can help mediate the protective effects of 1,25-dihydroxyvitamin D3 in experimental autoimmune encephalomyelitis in mice. Int. Immunol. 2015, 27, 237-244. [CrossRef] [PubMed]

72. Yu, S.; Cantorna, M.T. The vitamin D receptor is required for iNKT cell development. Proc. Natl. Acad. Sci. USA 2008, 105, 5207-5212. [CrossRef]

73. Cantorna, M.T.; McDaniel, K.; Bora, S.; Chen, J.; James, J. Vitamin D, immune regulation, the microbiota, and inflammatory bowel disease. Exp. Biol. Med. 2014, 239, 1524-1530. [CrossRef] [PubMed]

74. Bruce, D.; Yu, S.; Ooi, J.H.; Cantorna, M.T. Converging pathways lead to overproduction of IL-17 in the absence of vitamin D signaling. Int. Immunol. 2011, 23, 519-528. [CrossRef]

75. Muller, K.; Odum, N.; Bendtzen, K. 1,25-dihydroxyvitamin D3 selectively reduces interleukin-2 levels and proliferation of human T cell lines in vitro. Immunol. Lett. 1993, 35, 177-182. [CrossRef]

76. Rigby, W.F.; Noelle, R.J.; Krause, K.; Fanger, M.W. The effects of 1,25-dihydroxyvitamin D3 on human T lymphocyte activation and proliferation: A cell cycle analysis. J. Immunol. 1985, 135, 2279-2286. [PubMed]

77. Ochs, H.D.; Gambineri, E.; Torgerson, T.R. IPEX, FOXP3 and regulatory T-cells: A model for autoimmunity. Immunol. Res. 2007, 38, 112-121. [CrossRef] [PubMed]

78. Daniel, C.; Sartory, N.A.; Zahn, N.; Radeke, H.H.; Stein, J.M. Immune modulatory treatment of trinitrobenzene sulfonic acid colitis with calcitriol is associated with a change of a T helper (Th) 1/Th17 to a Th2 and regulatory T cell profile. J. Pharmacol. Exp. Ther. 2008, 324, 23-33. [CrossRef]

79. Yu, S.; Bruce, D.; Froicu, M.; Weaver, V.; Cantorna, M.T. Failure of T cell homing, reduced CD4/CD8 alpha alpha intraepithelial lymphocytes, and inflammation in the gut of vitamin D receptor KO mice. Proc. Natl. Acad. Sci. USA 2008, 105, 20834-20839. [CrossRef] [PubMed]

80. Bruce, D.; Cantorna, M.T. Intrinsic requirement for the vitamin D receptor in the development of CD8alphaalpha-expressing T cells. J. Immunol. 2011, 186, 2819-2825. [CrossRef]

81. Waterhouse, M.; Hope, B.; Krause, L.; Morrison, M.; Protani, M.M.; Zakrzewski, M.; Neale, R.E. Vitamin D and the gut microbiome: A systematic review of in vivo studies. Eur. J. Nutr. 2019, 58, 2895-2910. [CrossRef]

82. Wang, J.; Thingholm, L.B.; Skiecevičie, J.; Rausch, P.; Kummen, M.; Hov, J.R.; Degenhardt, F.; Heinsen, F.A.; Rühlemann, M.C.; Szymczak, S.; et al. Genome-wide association analysis identifies variation in Vitamin D receptor and other host factors influencing the gut microbiota. Nat. Genet. 2016, 48, 1396-1406. [CrossRef]

83. Cantorna, M.T.; Snyder, L.; Arora, J. Vitamin A and vitamin D regulate the microbial complexity, barrier function, and the mucosal immune responses to ensure intestinal homeostasis. Crit. Rev. Biochem. Mol. Biol. 2019, 54, 184-192. [CrossRef]

84. Lu, R.; Zhang, Y.G.; Xia, Y.; Zhang, J.; Kaser, A.; Blumberg, R.; Sun, J. Paneth Cell Alertness to Pathogens Maintained by Vitamin D Receptors. Gastroenterology 2021, 160, 1269-1283. [CrossRef]

85. Ooi, J.H.; Li, Y.; Rogers, C.J.; Cantorna, M.T. Vitamin D regulates the gut microbiome and protects mice from dextran sodium sulfate-Induced colitis-3. J. Nutr. 2013, 143, 1679-1686. [CrossRef] [PubMed]

86. Gubatan, J.; Mehigan, G.A.; Villegas, F.; Mitsuhashi, S.; Longhi, M.S.; Malvar, G.; Csizmadia, E.; Robson, S.; Moss, A.C. Cathelicidin Mediates a Protective Role of Vitamin D in Ulcerative Colitis and Human Colonic Epithelial Cells. Inflamm. Bowel Dis. 2020, 26, 885-897. [CrossRef]

87. D’Argenio, G.; Cosenza, V.; Sorrentini, I.; De Ritis, F.; Gatto, A.; Delle Cave, M.; D’Armiento, F.P.; Mazzacca, G. Butyrate, mesalamine, and factor XIII in experimental colitis in the rat: Effects on transglutaminase activity. Gastroenterology 1994, 106, 399-404. [CrossRef]

88. Pols, T.W.H.; Puchner, T.; Korkmaz, H.I.; Vos, M.; Soeters, M.R.; De Vries, C.J.M. Lithocholic acid controls adaptive immune responses by inhibition of Th1 activation through the Vitamin D receptor. PLoS ONE 2017, 12, e0176715. [CrossRef]

89. Szaleniec, M.; Wojtkiewicz, A.M.; Bernhardt, R.; Borowski, T.; Donova, M. Bacterial steroid hydroxylases: Enzyme classes, their functions and comparison of their catalytic mechanisms. Appl. Microbiol. Biotechnol. 2018, 102, 8153-8171. [CrossRef] [PubMed]

90. Bora, S.A.; Kennett, M.J.; Smith, P.B.; Patterson, A.D.; Cantorna, M.T. The Gut Microbiota Regulates Endocrine Vitamin D Metabolism through Fibroblast Growth Factor 23. Front. Immunol. 2018, 9, 408. [CrossRef]

91. Garg, M.; Hendy, P.; Ding, J.N.; Shaw, S.; Hold, G.; Hart, A. The Effect of Vitamin D on Intestinal inflammation and Faecal Microbiota in Patients with Ulcerative Colitis. J. Crohn's Colitis 2018, 12, 963-972. [CrossRef] [PubMed]

92. Jorgensen, S.P.; Agnholt, J.; Glerup, H.; Lyhne, S.; Villadsen, G.E.; Hvas, C.L.; Bartels, L.E.; Kelsen, J.; Christensen, L.A.; Dahlerup, J.F. Clinical trial: Vitamin D3 treatment in Crohn's disease-A randomized double-blind placebo-controlled study. Aliment. Pharmacol. Ther. 2010, 32, 377-383. [CrossRef]

93. Schaffler, H.; Herlemann, D.P.; Klinitzke, P.; Berlin, P.; Kreikemeyer, B.; Jaster, R.; Lamprecht, G. Vitamin D administration leads to a shift of the intestinal bacterial composition in Crohn's disease patients, but not in healthy controls. J. Dig. Dis. 2018, 19, 225-234 [CrossRef] [PubMed]

94. Soltys, K.; Stuchlikova, M.; Hlavaty, T.; Gaalova, B.; Budis, J.; Gazdarica, J.; Krajcovicova, A.; Zelinkova, Z.; Szemes, T.; Kuba, D.; et al. Seasonal changes of circulating 25-hydroxyvitamin D correlate with the lower gut microbiome composition in inflammatory bowel disease patients. Sci. Rep. 2020, 10, 6024. [CrossRef]

95. Chatu, S.; Chhaya, V.; Holmes, R.; Neild, P.; Kang, J.Y.; Pollok, R.C.; Poullis, A. Factors associated with vitamin D deficiency in a multicultural inflammatory bowel disease cohort. Front. Gastroenterol. 2013, 4, 51-56. [CrossRef] 
96. Pallav, K.; Riche, D.; May, W.L.; Sanchez, P.; Gupta, N.K. Predictors of Vitamin D deficiency in inflammatory bowel disease and health: A Mississippi perspective Retrospective Study. World J. Gastroenterol. 2017, 23, 638-645. [CrossRef]

97. Lim, W.C.; Hanauer, S.B.; Li, Y.C. Mechanisms of disease: Vitamin D and inflammatory bowel disease. Nat. Clin. Pract. Gastroenterol. Hepatol. 2005, 2, 308-315. [CrossRef]

98. Valvano, M.; Magistroni, M.; Mancusi, A.; Ascenzo, D.; Longo, S.; Stefanelli, G.; Vernia, F.; Viscido, A.; Necozione, S.; Latella, G. The Usefulness of Serum Vitamin D Levels in the Assessment of IBD Activity and Response to Biologics. Nutrients 2021, 13, 323. [CrossRef]

99. Yamada, A.; Komaki, Y.; Komaki, F.; Haider, H.; Micic, D.; Pekow, J.; Dalal, S.; Cohen, R.D.; Cannon, L.; Umanskiy, K.; et al. The Correlation between Vitamin D Levels and the Risk of Postoperative Recurrence in Crohn's Disease. Digestion 2021, 102, 767-775. [CrossRef]

100. Gubatan, J.; Moss, A.C. Vitamin D in inflammatory bowel disease: More than just a supplement. Curr. Opin. Gastroenterol. 2018, 34, 217-225. [CrossRef] [PubMed]

101. Bafutto, M.; Oliveira, E.C.; Rezende Filho, J. Use of Vitamin D With Anti-Tumor Necrosis Factor Therapy for Crohn's Disease. Gastroenterol. Res. 2020, 13, 101-106. [CrossRef]

102. Ahamed, Z.R.; Dutta, U.; Sharma, V.; Prasad, K.K.; Popli, P.; Kalsi, D.; Vaishnavi, C.; Arora, S.; Kochhar, R. Oral Nano Vitamin D Supplementation Reduces Disease Activity in Ulcerative Colitis: A Double-Blind Randomized Parallel Group Placebo-controlled Trial. J. Clin. Gastroenterol. 2019, 53, e409-e415. [CrossRef]

103. Narula, N.; Cooray, M.; Anglin, R.; Muqtadir, Z.; Narula, A.; Marshall, J.K. Impact of High-Dose Vitamin D3 Supplementation in Patients with Crohn's Disease in Remission: A Pilot Randomized Double-Blind Controlled Study. Dig. Dis. Sci. 2017, 62, 448-455. [CrossRef]

104. Dadaei, T.; Safapoor, M.H.; Aghdaei, H.A.; Balaii, H.; Pourhoseingholi, M.A.; Naderi, N.; Zojaji, H.; Azimzadeh, P.; Mohammadi, P.; Zali, M.R. Effect of vitamin D3 supplementation on TNF- $\alpha$ serum level and disease activity index in Iranian IBD patients. Gastroenterol. Hepatol. Bed Bench 2015, 8, 49-55. [CrossRef] [PubMed]

105. De Bruyn, J.R.; Bossuyt, P.; Ferrante, M.; West, R.L.; Dijkstra, G.; Witteman, B.J.; Wildenberg, M.; Hoentjen, F.; Franchimont, D.; Clasquin, E.; et al. High-Dose Vitamin D Does Not Prevent Postoperative Recurrence of Crohn's Disease in a Randomized Placebo-Controlled Trial. Clin. Gastroenterol. Hepatol. 2021, 19, 1573-1582.e5. [CrossRef]

106. Sharifi, A.; Hosseinzadeh-Attar, M.J.; Vahedi, H.; Nedjat, S. A randomized controlled trial on the effect of vitamin D3 on inflammation and cathelicidin gene expression in ulcerative colitis patients. Saudi J. Gastroenterol. 2016, 22, 316-323. [CrossRef] [PubMed]

107. Mathur, J.; Naing, S.; Mills, P.; Limsui, D. A randomized clinical trial of vitamin D(3) (cholecalciferol) in ulcerative colitis patients with hypovitaminosis D(3). PeerJ 2017, 5, e3654. [CrossRef]

108. Tan, B.; Li, P.; Lv, H.; Yang, H.; Li, Y.; Li, J.; Wang, O.; Qian, J.M. Treatment of vitamin D deficiency in Chinese inflammatory bowel disease patients: A prospective, randomized, open-label, pilot study. J. Dig. Dis. 2018, 19, 215-224. [CrossRef] [PubMed]

109. Bendix, M.; Dige, A.; Deleuran, B.; Dahlerup, J.F.; Jørgensen, S.P.; Bartels, L.E.; Husted, L.B.; Harsløf, T.; Langdahl, B.; Agnholt, J. Flow cytometry detection of vitamin D receptor changes during vitamin D treatment in Crohn's disease. Clin. Exp. Immunol. 2015, 181, 19-28. [CrossRef] [PubMed]

110. Bendix-Struve, M.; Bartels, L.E.; Agnholt, J.; Dige, A.; Jørgensen, S.P.; Dahlerup, J.F. Vitamin D3 treatment of Crohns disease patients increases stimulated T cell IL-6 production and proliferation. Aliment. Pharmacol. Ther. 2010, 32, 1364-1372. [CrossRef]

111. Bartels, L.E.; Bendix, M.; Hvas, C.L.; Jørgensen, S.P.; Agnholt, J.; Agger, R.; Dahlerup, J.F. Oral vitamin D3 supplementation reduces monocyte-derived dendritic cell maturation and cytokine production in Crohn's disease patients. Inflammopharmacology 2014, 22, 95-103. [CrossRef] [PubMed]

112. Karimi, S.; Tabataba-Vakili, S.; Yari, Z.; Alborzi, F.; Hedayati, M.; Ebrahimi-Daryani, N.; Hekmatdoost, A. The effects of two vitamin D regimens on ulcerative colitis activity index, quality of life and oxidant/anti-oxidant status. Nutr. J. 2019, 18, 16. [CrossRef]

113. Arihiro, S.; Nakashima, A.; Matsuoka, M.; Suto, S.; Uchiyama, K.; Kato, T.; Mitobe, J.; Komoike, N.; Itagaki, M.; Miyakawa, Y.; et al. Randomized Trial of Vitamin D Supplementation to Prevent Seasonal Influenza and Upper Respiratory Infection in Patients with Inflammatory Bowel Disease. Inflamm. Bowel Dis. 2019, 25, 1088-1095. [CrossRef] [PubMed]

114. Garg, M.; Rosella, O.; Rosella, G.; Wu, Y.; Lubel, J.S.; Gibson, P.R. Evaluation of a 12-week targeted vitamin D supplementation regimen in patients with active inflammatory bowel disease. Clin. Nutr. 2018, 37, 1375-1382. [CrossRef] [PubMed]

115. Guzman-Prado, Y.; Samson, O.; Segal, J.P.; Limdi, J.K.; Hayee, B.H. Vitamin D Therapy in Adults with Inflammatory Bowel Disease: A Systematic Review and Meta-Analysis. Inflamm. Bowel Dis. 2020, 26, 1819-1830. [CrossRef] [PubMed]

116. Li, J.; Chen, N.; Wang, D.; Zhang, J.; Gong, X. Efficacy of vitamin D in treatment of inflammatory bowel disease: A meta-analysis. Medicine 2018, 97, e12662. [CrossRef]

117. Guo, Y.; Zhang, T.; Wang, Y.; Liu, R.; Chang, M.; Wang, X. Effects of oral vitamin D supplementation on inflammatory bowel disease: A systematic review and meta-analysis. Food Funct. 2021, 12, 7588-7606. [CrossRef] 
118. Winter, R.W.; Collins, E.; Cao, B.; Carrellas, M.; Crowell, A.M.; Korzenik, J.R. Higher 25-hydroxyvitamin D levels are associated with greater odds of remission with anti-tumour necrosis factor- $\alpha$ medications among patients with inflammatory bowel diseases. Aliment. Pharmacol. Ther. 2017, 45, 653-659. [CrossRef] [PubMed]

119. Gubatan, J.; Rubin, S.J.S.; Bai, L.; Haileselassie, Y.; Levitte, S.; Balabanis, T.; Patel, A.; Sharma, A.; Sinha, S.R.; Habtezion, A. Vitamin D Is Associated with $\alpha 4 \beta 7+$ Immunophenotypes and Predicts Vedolizumab Therapy Failure in Patients with Inflammatory Bowel Disease. J. Crohn's Colitis. 2021, 15, 1980-1990. [CrossRef] [PubMed] 